\title{
Towards understanding the kallikrein-kinin system: insights from measurement of kinin peptides
}

D.J. Campbell
St. Vincent's Institute of Medical Research, Fitzroy, Victoria, Australia

\begin{abstract}
Correspondence

D.J. Campbell

St. Vincent's Institute

of Medical Research

41 Victoria Parade

Fitzroy

Victoria 3065

Australia

Fax: +61-3-9416-2676

E-mail:

J.Campbell@ medicine.unimelb.edu.au

Presented at the III International Symposium on Vasoactive Peptides, Belo Horizonte, MG, Brasil, October 8-10, 1999.

Received November 26, 1999 Accepted February 3, 2000

The kallikrein-kinin system is complex, with several bioactive peptides that are formed in many different compartments. Kinin peptides are implicated in many physiological and pathological processes including the regulation of blood pressure and sodium homeostasis, inflammatory processes, and the cardioprotective effects of preconditioning. We established a methodology for the measurement of individual kinin peptides in order to study the function of the kallikreinkinin system. The levels of kinin peptides in tissues were higher than in blood, confirming the primary tissue localization of the kallikreinkinin system. Moreover, the separate measurement of bradykinin and kallidin peptides in man demonstrated the differential regulation of the plasma and tissue kallikrein-kinin systems, respectively. Kinin peptide levels were increased in the heart of rats with myocardial infarction, in tissues of diabetic and spontaneously hypertensive rats, and in urine of patients with interstitial cystitis, suggesting a role for kinin peptides in the pathogenesis of these conditions. By contrast, blood levels of kallidin, but not bradykinin, peptides were suppressed in patients with severe cardiac failure, suggesting that the activity of the tissue kallikrein-kinin system may be suppressed in this condition. Both angiotensin converting enzyme (ACE) and neutral endopeptidase (NEP) inhibitors increased bradykinin peptide levels. ACE and NEP inhibitors had different effects on kinin peptide levels in blood, urine, and tissues, which may be accounted for by the differential contributions of ACE and NEP to kinin peptide metabolism in the multiple compartments in which kinin peptide generation occurs. Measurement of the levels of individual kinin peptides has given important information about the operation of the kallikrein-kinin system and its role in physiology and disease states.
\end{abstract}

\section{Introduction}

Kinins are potent vasodilator oligopeptides that contain the nonapeptide bradyki$\operatorname{nin}[\mathrm{BK}-(1-9)]$ as part of their sequence. Kinins have effects on many different aspects of physiology, including the regulation of blood pressure and of renal and cardiac
Key words

- Bradykinin

- Kallidin

- Kallikrein

- Kininogen function, and have been implicated in the pathogenesis of hypertension and inflammation (for a review, see 1). Kinins may mediate in part the effects of angiotensin converting enzyme (ACE) and neutral endopeptidase 24.11 (NEP) inhibitors.

Kinins act via two types of kinin receptor, the type $1\left(B_{1}\right)$ and the type $2\left(B_{2}\right)$ receptors. 
The $\mathrm{B}_{2}$ receptor normally predominates, whereas $B_{1}$ receptors are induced by tissue injury, such as that which occurs following myocardial ischaemia (2) and inflammation (3). A complex variety of kinin peptides acts through these receptors. In man, plasma kallikrein forms bradykinin [BK-(1-9)] from high molecular weight (HMW) kininogen, whereas tissue kallikrein forms kallidin [Lys ${ }^{0}$ -

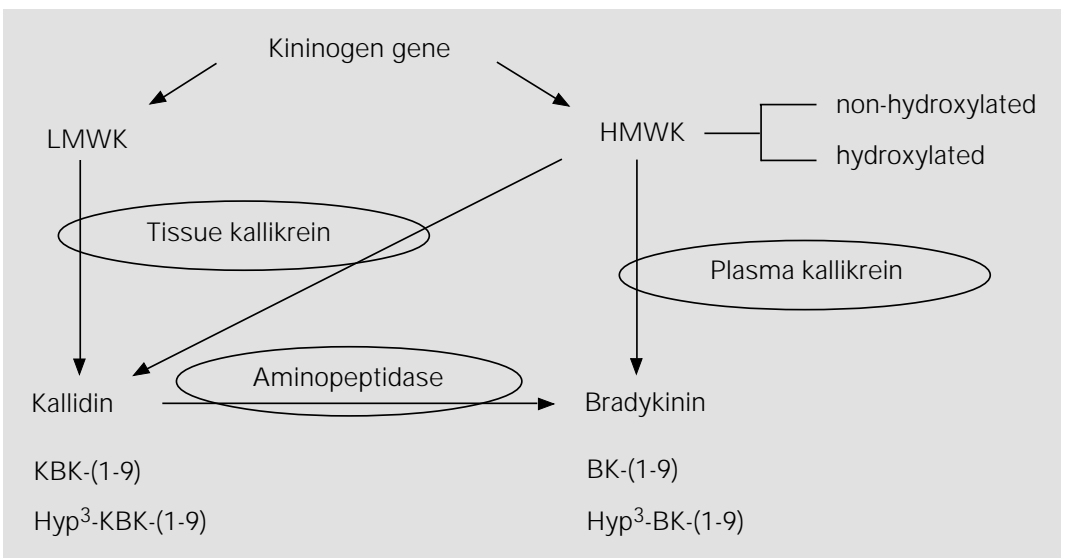

Figure 1 - Generation of kinin peptides by tissue and plasma kallikrein. In man tissue kallikrein generates kallidin whereas plasma kallikrein generates bradykinin (BK). However, in the rat both tissue and plasma kallikrein generate bradykinin. LMWK, HMWK, Low and high molecular weight kininogens, respectively; KBK, kallidin (Lys ${ }^{0}$-bradykinin); Hyp ${ }^{3}$, hydroxylated proline.

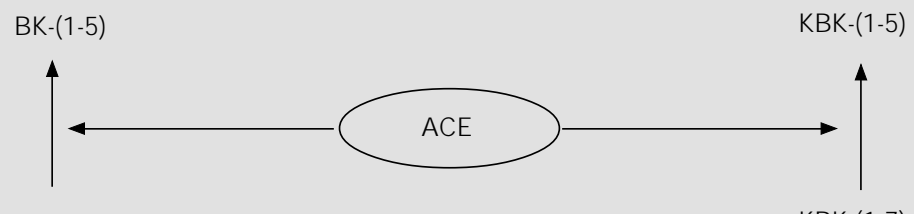

BK-(1-7)

KBK-(1-7)

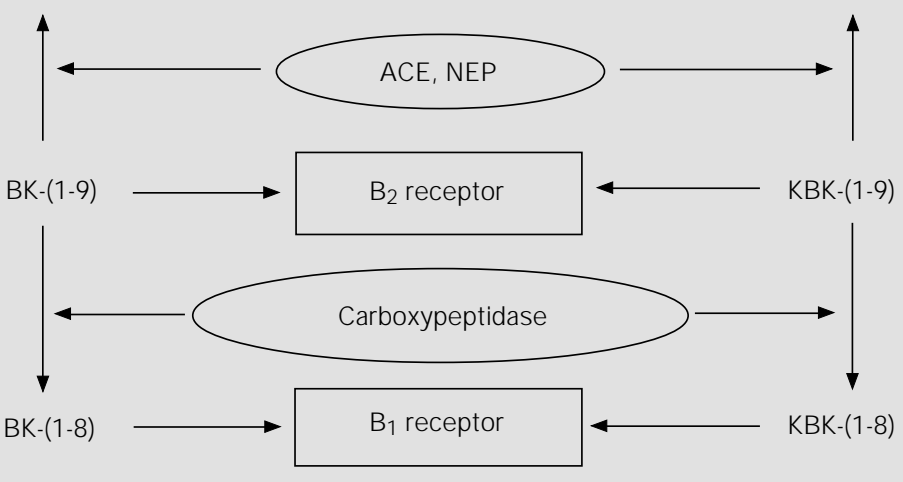

Figure 2 - Kinin peptides and kinin receptors. Whereas bradykinin [BK-(1-9)] and kallidin [KBK(1-9)] are more potent agonists of the $B_{2}$ receptor, BK-(1-8) and KBK-(1-8) are more potent agonists of the $B_{1}$ receptor. ACE, Angiotensin converting enzyme; NEP, neutral endopeptidase; BK, bradykinin; KBK, Lys ${ }^{0}$-bradykinin.
BK-(1-9), KBK-(1-9)] from low molecular weight (LMW) and HMW kininogens (1). Moreover, bradykinin peptides may be generated by aminopeptidase-mediated cleavage of kallidin peptides (Figure 1). These peptides are more potent at the $\mathrm{B}_{2}$ receptor (4) (Figure 2). A proportion of kinins is hydroxylated on proline ${ }^{3}$ of the BK-(1-9) sequence (5), and hydroxylated kinins have similar biological activity to non-hydroxylated kinins (4). Enzymes collectively called kininases metabolize these kinins (Figure 3). The carboxypeptidase (kininase I) metabolites of BK-(1-9) and KBK-(1-9) are bradykinin-(1-8) [BK-(1-8)] and Lys ${ }^{0}$-bradykinin(1-8) [KBK-(1-8)], respectively, which are also bioactive, but more potent on $\mathrm{B}_{1}$ receptors (4), whereas the ACE and NEP metabolites bradykinin-(1-7) [BK-(1-7)] and Lys ${ }^{0}$ bradykinin-(1-7) [KBK-(1-7)] are inactive (Figure 2). Kinin peptides are less complex in the rat than in man. In the rat both plasma and tissue kallikrein generate BK-(1-9), and kinin peptides are not hydroxylated in rodents.

Despite its long history, many aspects of the physiology of bradykinin peptides and their role in disease states are yet to be defined. The sole sources of kinin peptides are the kininogens. Kininogen deficiency in man is reported to be relatively asymptomatic, suggesting that kinin peptides may have little role in normal physiology. Although the detection of these patients is due to their severe abnormality in surface-activated intrinsic coagulation, fibrinolytic and kiningenerating pathways, these patients have little or no bleeding abnormality $(6,7)$. However, studies in experimental animals provide evidence for an important role for kinin peptides in the regulation of blood pressure and sodium homeostasis, and in contributing to inflammatory processes (8-11). The $\mathrm{B}_{2}$ receptor gene knockout mouse is hypertensive with cardiac hypertrophy (8). Both the $\mathrm{B}_{2}$ receptor gene knockout mouse and the kininogen-deficient Brown-Norway Katholiek 
rat strain show increased sensitivity to the pressor effects of increased dietary salt, mineralocorticoid administration, and angiotensin II (Ang II) infusion, and an impairment of the cardioprotective effects of preconditioning (8-11). In addition, the BrownNorway Katholiek rat strain shows a reduced response to inflammatory stimuli (10).

There have been many different approaches to the study of the kallikrein-kinin system. One approach has been the measurement of kallikrein and kininogen levels in blood, urine and tissues. However, there may be difficulties in the interpretation of such studies. For example, alternative pathways of kinin formation involving enzymes other than kallikreins may operate in disease states. Although LMW kininogen is a poor substrate for plasma kallikrein, it will form BK(1-9) in the presence of neutrophil elastase, which, by cleaving a fragment from LMW kininogen, renders LMW kininogen much more susceptible to cleavage by plasma kallikrein (12). Moreover, the combination of mast cell tryptase and neutrophil elastase releases BK-(1-9) from oxidized kininogens that are resistant to cleavage by kallikreins (13). Furthermore, endogenous inhibitors of kallikrein activity may modulate the activity of kallikrein in vivo, and kallikrein and prekallikrein may be activated during sample processing. In addition, kininase activity is a critical determinant of the activity of the kallikrein-kinin system through the modulation of kinin peptide levels in vivo.

My laboratory focussed on the measurement of kinin peptides to better understand the functioning of the kallikrein-kinin system. Initially, we developed amino-terminal-directed radioimmunoassays (RIA) for BK-(1-9), its kininase I metabolite BK-(1-8), and the biologically inactive ACE and NEP metabolite BK-(1-7) (14,15). BK-(1-7), BK(1-8), and BK-(1-9) were separated by high performance liquid chromatography (HPLC) before RIA. Calculation of the BK-(1-7)/ BK-(1-9) and BK-(1-8)/BK-(1-9) ratios provided indices of the rate of BK-(1-9) metabolism to BK-(1-7) and BK-(1-8), respectively. We applied these assays to the measurement of kinin peptides in blood, urine, and tissues of rats and dogs (14-27). Subsequently, we developed amino-terminal-directed RIA for the corresponding kallidin peptides (28-30). These bradykinin and kallidin peptide RIA were also able to measure hydroxylated bradykinin and kallidin peptides. We were able to separate non-hydroxylated and hydroxylated bradykinin and kallidin peptides by HPLC, thus enabling measurement of 6 bradykinin peptides [non-hydroxylated and hydroxylated BK-(1-7), BK(1-8), BK-(1-9)] and 6 kallidin peptides [nonhydroxylated and hydroxylated KBK-(1-7),

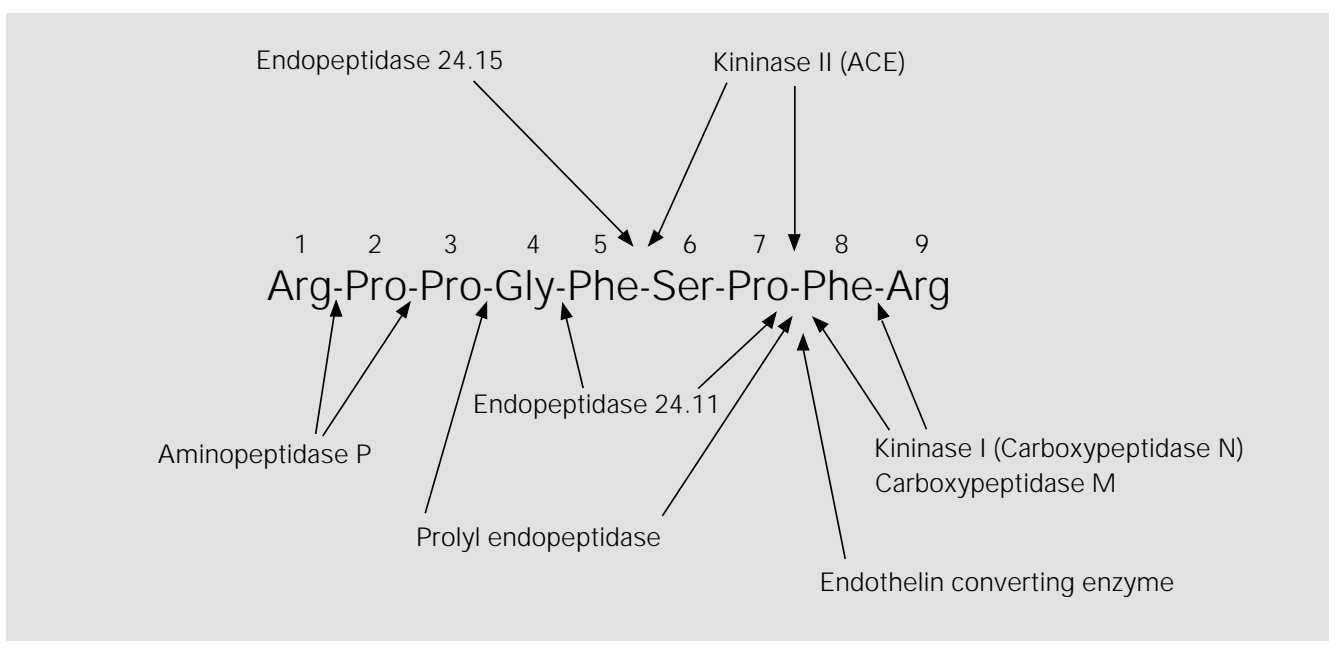

Figure 3 - Metabolism of kinin peptides. Some of the enzymes that metabolize kinin peptides are shown with their sites of cleavage of the kinin molecule. ACE, Angiotensin converting enzyme. 
KBK-(1-8), KBK-(1-9)] in blood, urine, and tissue of man.

The purpose of this brief review is to summarize what we have learnt about the kallikrein-kinin system from measurement of kinin peptide levels, and to discuss these findings in relation to data obtained from alternative approaches to the study of the kallikrein-kinin system.

\section{Kinin peptide levels in blood and tissues}

Circulating levels of kinin peptides are very low, usually less than $3 \mathrm{fmol} / \mathrm{ml}$. We attribute the higher levels reported in previous studies to a failure to adequately prevent artefactual generation of kinin peptides during sample collection and processing. Much higher levels of kinin peptides are measured during acute episodes of angio-oedema (31). The maintenance of low levels of kinin peptides is relevant to the success of ACE and NEP inhibitor therapy. There is considerable evidence for a role for kinin peptides in mediating some of the effects of ACE and NEP inhibition. However, these inhibitors are generally free of the side effects one might expect from increased kinin peptide levels. For example, increased endothelial

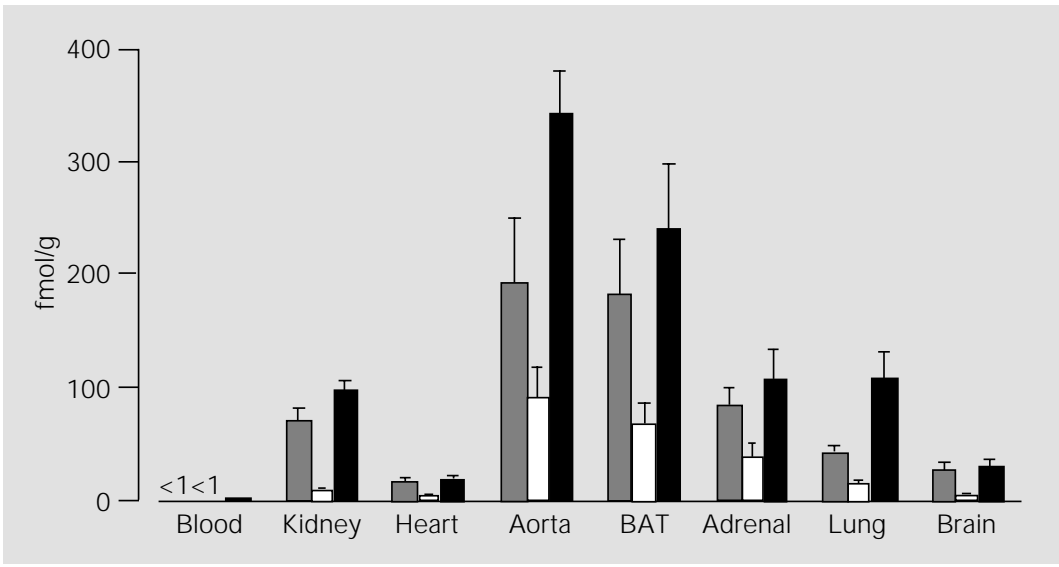

Figure 4 - Levels of BK-(1-7) (gray columns), BK-(1-8) (open columns), and BK-(1-9) (black columns) in blood, kidney, heart, aorta, brown adipose tissue (BAT), adrenal, lung, and brain of normal male Sprague Dawley rats. Data are reported as mean \pm SEM. (Reproduced from Ref. 14). permeability, such as that manifest in angiooedema, is an infrequent complication of ACE inhibitor therapy. The low incidence of side effects with ACE and NEP inhibitor therapy indicates that kinin peptide levels are low, even in the presence of ACE and/or NEP inhibition, and thus any effect of ACE and NEP inhibition on kinin peptide levels must be subtle. This is to be expected, given the many different kininases that metabolize kinin peptides (Figure 3). The relative proportions of these different kininases may vary between different tissue compartments. Any effect of ACE or NEP inhibition on kinin peptide levels in a particular compartment will depend on the relative contribution of ACE and NEP to kinin peptide metabolism in that compartment.

In studies in normal rats, tissue levels of kinin peptides were higher than circulating levels, consistent with tissues being the main site of formation of kinin peptides (Figure 4). We found increased levels of kinin peptides in tissues of rats with myocardial infarction, in diabetic rats, and in spontaneously hypertensive rats (SHR) $(21,26,32)$. In rats with myocardial infarction, BK-(1-9) levels were increased in heart on day 2 and 3 post-infarction, associated with a decrease in the BK-(1-7)/BK-(1-9) ratio, suggesting reduced metabolism of BK-(1-9) to BK-(1-7) in this tissue. The increased cardiac BK(1-9) levels in the acute phase of myocardial infarction were consistent with a role for this peptide in cardioprotection and limitation of infarct size $(33,34)$. In diabetic rats, the levels of BK-(1-9) and its metabolite BK-(1-7) were increased in kidney, aorta, and heart. The increased BK-(1-9) levels were consistent with the participation of this peptide in the vascular and metabolic abnormalities of diabetes, in particular the glomerular hyperfiltration, increased glomerular plasma flow, and elevated glomerular capillary hydraulic pressure of early insulin-dependent diabetes (35). The increased levels of BK-(1-9) and its metabolites in kidney, adrenal, lung, and 
heart of young SHR suggested increased kallikrein activity in these tissues. Moreover, the reduced BK-(1-7)/BK-(1-9) and BK-(1-8)/BK-(1-9) ratios in kidney of SHR indicated reduced endopeptidase and carboxypeptidase-mediated metabolism of BK(1-9), that may have contributed to the increased BK-(1-9) levels in this tissue. When taken together with the previously reported hypotensive effect of $\mathrm{B}_{2}$ receptor antagonism in young SHR (36), and the cosegregation of the SHR kallikrein gene with blood pressure (37), the increased BK-(1-9) levels in tissues of young SHR were consistent with a role for this peptide in the pathogenesis of hypertension in these rats.

In man, the generation of bradykinin and kallidin peptides by plasma and tissue kallikrein, respectively, enabled differentiation between the role of plasma and tissue kallikrein in kinin peptide formation. In blood and atrial tissue we found bradykinin peptides to be more abundant than kallidin peptides, whereas kallidin peptides were more abundant in urine (28-30). Bradykinin and kallidin peptide levels were higher in venous than arterial blood, consistent with the formation of these peptides in tissues. Further evidence for the formation of kinin peptides in tissue was the higher level of bradykinin and kallidin peptides in atrial tissue than in blood.

We investigated whether the kallikreinkinin system is activated in interstitial cystitis, a chronic inflammatory condition of the bladder wall, by measuring urinary excretion rates of kinin peptides. Catheter urine was collected from subjects during a water diuresis $(\sim 10 \mathrm{ml} / \mathrm{min})$ before and after distension of the bladder with $100 \mathrm{ml}$ water, and the contribution of the bladder wall to urinary kinin peptides was assessed by measuring the change in kinin peptide levels after 2 min of bladder stasis before and after distension. We found increased urinary excretion rates of bradykinin, but not kallidin, peptides after 2-min bladder stasis after blad- der distension (28). These findings provided evidence for increased bradykinin peptide levels in the bladder wall of subjects with interstitial cystitis, where these peptides may participate in the pathogenesis and symptomatology of this condition.

In comparison with normal subjects, patients with severe cardiac failure, who were receiving ACE inhibitor therapy, had increased blood levels of bradykinin peptides but suppressed blood levels of kallidin peptides (30). This suppression of blood kallidin peptide levels despite ACE inhibitor therapy suggested that the activity of the tissue kallikrein-kinin system may be suppressed in severe cardiac failure.

\section{Feedback regulation of the kallikrein-kinin system}

The role of endogenous kinin peptides has been determined mainly by study of the effects of kinin antagonists, most often the $\mathrm{B}_{2}$ receptor antagonist icatibant (D-Arg$\left[\mathrm{Hyp}^{3}, \mathrm{Thi}^{5}, \mathrm{D}-\mathrm{Tic}^{7}, \mathrm{Oic}^{8}\right]$-bradykinin). However, interpretation of the effects of $B_{2}$ receptor antagonists has been compromised by lack of information concerning the effects of these antagonists on endogenous kinin peptide levels. If kinin peptide levels were subject to short loop feedback regulation mediated through $\mathrm{B}_{2}$ receptors, then a reactive increase in kinin peptide levels may blunt the effects of $B_{2}$ receptor antagonism and stimulate $B_{1}$ receptors. We investigated whether endogenous kinin peptide levels are subject to short loop feedback regulation mediated through the $\mathrm{B}_{2}$ receptor by administering icatibant $(1 \mathrm{mg} / \mathrm{kg})$ to rats by intraperitoneal injection, and measuring circulating and tissue levels of kinin peptides after $4 \mathrm{~h}$ (25). Icatibant did not influence circulating or tissue levels of bradykinin peptides, thus demonstrating that kinin peptide levels are not subject to short loop feedback regulation mediated through $\mathrm{B}_{2}$ receptors. 
Figure 5 - Dose-response effects of perindopril on BK-(1-9) levels (A) and BK-(1-7)/BK-(1-9) ratios (B) in plasma (open circles), kidney (filled circles), lung (triangles), heart (filled squares), and aorta (open squares) of normal male Sprague Dawley rats administered perindopril in the drinking water for 7 days. Data are reported as the ratio to the mean of the respective control group. Error bars and significance levels are not shown. (Redrawn from Ref. 17).
In contrast to these findings, Siragy et al. (38) reported that icatibant increased immunoreactive kinin peptide levels in renal interstitial fluid collected by microdialysis probe from sodium-deficient dogs. The difference between our findings and those of Siragy et al. (38) may be due to differences between species, or to differences in sodium status. Moreover, the identity of the immunoreactive material measured by Siragy et al. (38) is uncertain, as is the effect of the chronically indwelling microdialysis probe on kinin peptide formation.

\section{Effects of ACE inhibition on kinin peptide levels}

Many studies implicate kinin peptides in the effects of ACE inhibitors, including their effects on blood pressure and cardiac hypertrophy (39-41). We studied the effects of ACE inhibition on kinin peptide levels in both experimental animals and in man. The dose-related effects of ACE inhibitors on circulating and tissue levels of angiotensin

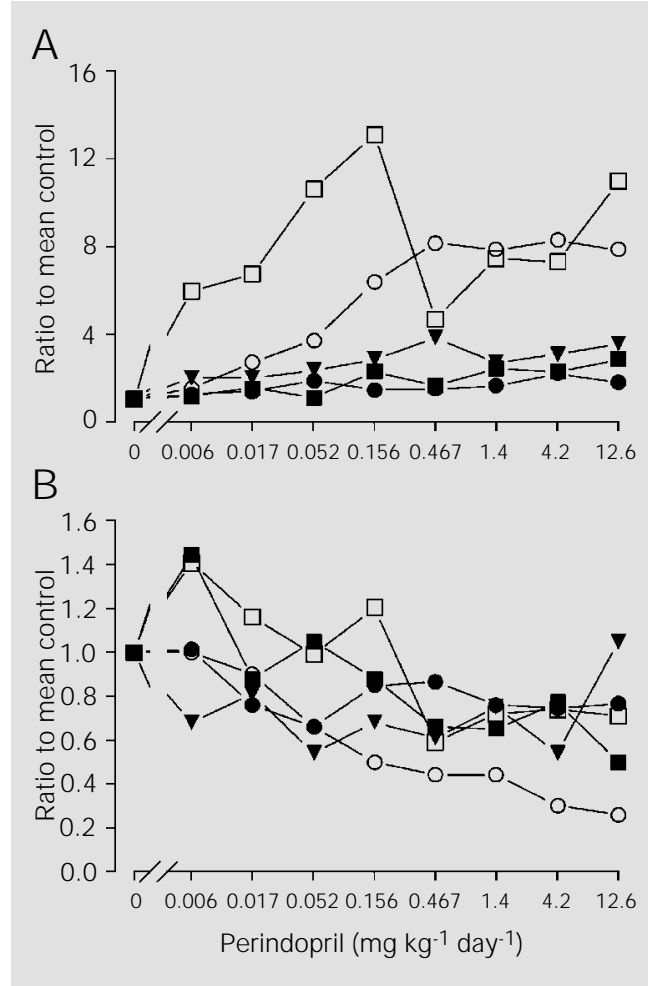

and bradykinin peptides were examined by administration of the ACE inhibitor perindopril or lisinopril to rats in the drinking water for 7 days (17). Perindopril increased circulating BK-(1-9) levels $\sim 8$-fold with a threshold dose of $0.052 \mathrm{mg} \mathrm{kg}^{-1}$ day $^{-1}$, and increased BK-(1-9) levels in kidney, heart and lung in parallel with the changes observed for blood (Figure 5). By contrast, aortic and brown adipose tissue BK-(1-9) and BK-(1-7) levels increased several-fold for perindopril doses as low as $0.006 \mathrm{mg} \mathrm{kg}^{-1} \mathrm{day}^{-1}$. Lisinopril also increased aortic BK-(1-9) and BK-(1-7) levels at doses below the threshold for decrease in Ang II/Ang I ratio. These data indicated that vascular BK-(1-9) levels responded to low doses of ACE inhibitor, and may be important mediators of the effects of these compounds. Moreover, the increase in vascular kinin peptide levels at doses of ACE inhibitor below the apparent threshold for ACE inhibition led us to propose that these compounds increase kinin peptide levels by inhibition of a non-ACE kininase. This concept is discussed later in this section.

We investigated the effects of ACE inhibition on kinin peptide levels in rats with myocardial infarction. Perindopril increased BK-(1-9) levels in heart by $45 \%$, which did not achieve statistical significance, although there was a statistically significant reduction in the BK-(1-7)/BK-(1-9) ratio in heart, indicating inhibition of cardiac metabolism of BK-(1-9) by perindopril. We also showed that ACE inhibition with either perindoprilat or enalaprilat increased blood levels of kinin peptides in dogs with pacing-induced heart failure (27).

In both rats and dogs we found that ACE inhibition increased the levels of both BK(1-9) and its metabolite BK-(1-7), although there was suppression of the BK-(1-7)/BK(1-9) ratio $(17,27)$. As shown in Figure 2, BK-(1-7) is both the product of BK-(1-9) metabolism by ACE and the substrate for its subsequent metabolism to BK-(1-5). The in- 
crease in BK-(1-7) levels during ACE inhibition suggests that ACE inhibition has greater impact on BK-(1-7) metabolism than BK-(1-7) formation. Thus, in comparison with other kininases, ACE has a more dominant role in BK-(1-7) metabolism than BK(1-9) metabolism.

Our studies in man demonstrated a differential regulation of bradykinin and kallidin peptides in blood, and differential regulation of kinin peptide levels in blood and atrial tissue. ACE inhibition increased blood levels of bradykinin but not kallidin peptides in man (30). Moreover, ACE inhibition did not modify bradykinin or kallidin peptide levels or the BK-(1-7)/BK-(1-9) ratio in atrial tissue of patients undergoing cardiac surgery, although Ang II levels and Ang II/Ang I ratio in atrial tissue were reduced (29). We consider it unlikely that the increase in blood levels of bradykinin, but not kallidin, peptides was due to artefactual generation of bradykinin peptides by plasma kallikrein during sample collection because ACE inhibition would be expected to protect bradykinin and kallidin peptides to a similar degree. A more likely explanation for the differential effects of ACE inhibition on blood levels of bradykinin and kallidin peptides is the formation of bradykinin and kallidin peptides in different compartments, where ACE may make a greater or lesser contribution to kinin metabolism. Thus, if ACE were a major kininase in the compartment where bradykinin peptides were formed, one would expect ACE inhibition to increase bradykinin peptide levels. By contrast, if non-ACE kininases were predominant in the compartment where kallidin peptides were formed, ACE inhibition may not affect kallidin peptide levels.

Our finding that ACE inhibition did not modify bradykinin or kallidin peptide levels in atrial tissue is evidence against a role for changes in cardiac kinin peptide levels in mediating the therapeutic effects of ACE inhibition. It is possible that other enzymes such as NEP (42), neutral endopeptidase 24.15 (43), and aminopeptidase $P$ (44) play a greater role than ACE in kinin metabolism in the interstitium of atrial tissue.

Since the discovery of ACE inhibitors there has been debate as to whether some of the effects of these compounds may be due to mechanisms other than inhibition of ACE enzymatic activity $(45,46)$. Greene et al. (45) noted that ACE inhibition potentiated the effects of BK-(1-9) analogues that were resistant to cleavage by ACE, and concluded that the mechanism of potentiation may be independent of kininase inhibition. These authors suggested that this non-kininase mechanism might involve the kinin receptor. In our own studies of the dose-related effects of ACE inhibition on vascular bradykinin peptide levels, described earlier, we found that ACE inhibition increased bradykinin peptide levels at doses that appeared to be below the threshold for ACE inhibition (17). These findings led us to propose that ACE inhibitors may also inhibit a non-ACE kininase in vasculature (46). We also proposed that this non-ACE kininase may cleave the ACE-resistant BK-(1-9) analogues used by Greene et al. (45). Thus, the inhibition of such a non-ACE kininase may account for the potentiation by ACE inhibition of the effects of BK-(1-9) analogues resistant to cleavage by ACE. This putative non-ACE kininase has yet to be confirmed, although ACE inhibitors have been shown to inhibit aminopeptidase P (47) and other enzymes (46). It is of note that there are difficulties in comparing the potentiation of the effects of kinin peptides and the inhibition of Ang I conversion to Ang II by ACE inhibition. In circumstances where ACE is the major mechanism of conversion of Ang I to Ang II, the rate of conversion is a valid index of ACE inhibition. However, if kinin peptide degradation is very efficient, then minimal kininase inhibition may produce a large potentiation of kinin peptide levels and their effects. For example, in normal rats $98 \%$ of circulating 
BK-(1-9) disappears in one passage through the pulmonary vascular bed (48). If lung kininase activity were reduced by $2 \%$ such that $96 \%$ of circulating BK-(1-9) disappeared in one passage through the pulmonary vascular bed, then the biological effects of intravenously administered BK-(1-9) would be increased 2-fold.

Recent studies support the proposal that ACE inhibitors may interact with the kinin receptor, although this interaction appears to be indirect, and mediated by cross-talk between ACE and the $B_{2}$ receptor $(49,50)$. There is evidence that this cross-talk may involve more than one mechanism. Marcic et al. (49) found that a variety of ACE inhibitors and ACE substrates, including angiotensin-(1-7), were able to resensitise the $B_{2}$

Figure 6 - Effects of ecadotril administration alone (open columns) and together with $0.2 \mathrm{mg}$ $\mathrm{kg}^{-1}$ day ${ }^{-1}$ perindopril (closed columns) on the heart weight/body weight ratio (upper panel) and heart BK-(1-9) levels (lower panel) in rats with myocardial infarction. Each value represents the mean \pm SEM. ${ }^{*} \mathrm{P}<0.05$, $* * \mathrm{P}<0.01$ in comparison with vehicle-treated control, $\mathrm{N}=9-10$ rats per group. (Redrawn from Ref. 24).

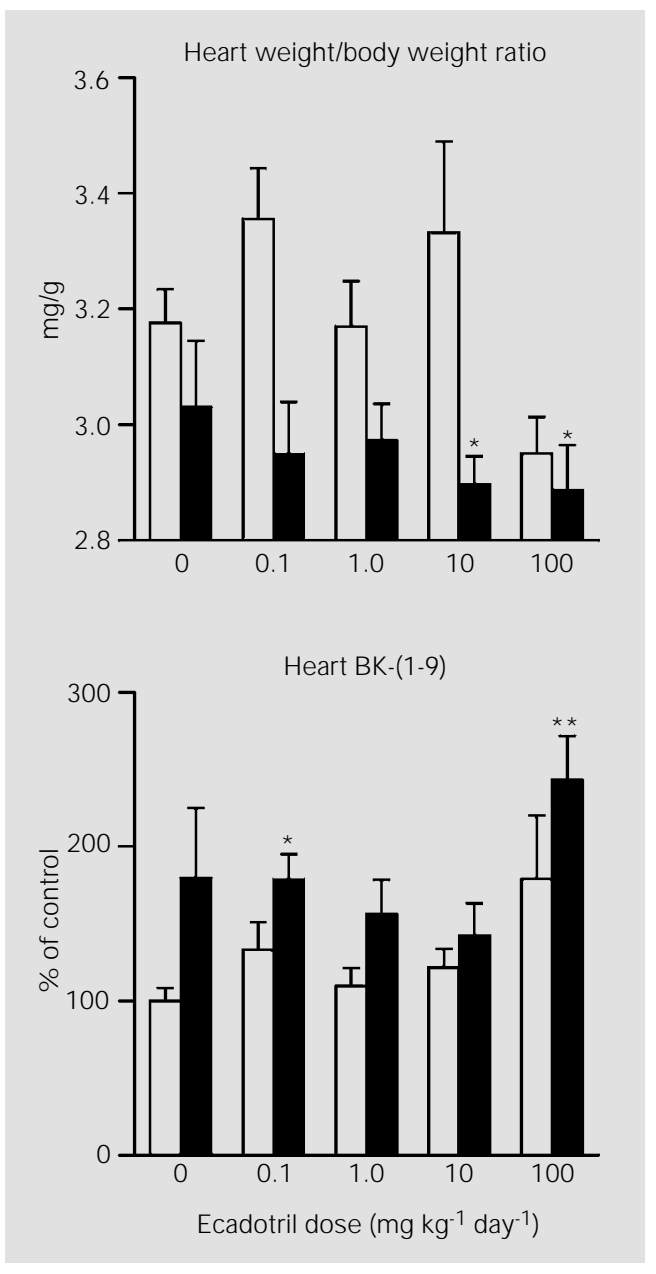

receptor. By contrast, Benzing et al. (50) found that the ACE substrate hippuryl-Lhistidyl-L-leucine did not reproduce the effects of ramiprilat on $\mathrm{B}_{2}$ receptor translocation and reactivation of signaling events initiated by the $\mathrm{B}_{2}$ receptor. Thus, it would appear that different aspects of $\mathrm{B}_{2}$ receptor function show differential modulation by ACE substrates.

\section{Effects of combined ACE and NEP inhibition}

The combination of NEP and ACE inhibition is a candidate therapy for hypertension and cardiac failure. Given that NEP and ACE metabolize angiotensin and bradykinin peptides, we investigated the effects of NEP inhibition and combined NEP and ACE inhibition on the levels of these peptides in both normal Sprague Dawley rats and in rats with myocardial infarction $(23,24)$. For normal rats we administered the NEP inhibitor ecadotril $\left(0,0.1,1,10,100 \mathrm{mg} \mathrm{kg}^{-1}\right.$ day $\left.^{-1}\right)$, either alone or together with a submaximal dose of perindopril $\left(0.2 \mathrm{mg} \mathrm{kg}^{-1} \mathrm{day}^{-1}\right)$, to rats by 12 hourly gavage for 7 days (23). Ecadotril produced diuresis, natriuresis, and increased urine cyclic GMP and BK-(1-9) levels. Perindopril increased BK-(1-9) levels in blood, kidney, and aorta. Combined NEP/ACE inhibition produced the summation of these effects of separate NEP and ACE inhibition. In addition, perindopril potentiated the ecadotril-mediated diuresis, natriuresis and decrease in urine BK-(1-7)/ BK-(1-9) ratio. This study demonstrated that combined NEP/ACE inhibition produced greater inhibition of kinin peptide metabolism than either inhibitor alone, leading to enhanced effects on diuresis and natriuresis.

In rats with myocardial infarction we administered ecadotril $(0,0.1,1,10,100 \mathrm{mg}$ $\mathrm{kg}^{-1}$ day $^{-1}$ ), either alone or together with a submaximal dose of perindopril $\left(0.2 \mathrm{mg} \mathrm{kg}^{-1}\right.$ day $^{-1}$ ) by 12 hourly gavage from day 2 to 28 post-infarction (24). Neither perindopril nor 
ecadotril reduced cardiac hypertrophy when administered separately, whereas the combination of perindopril and 10 or $100 \mathrm{mg} \mathrm{kg}^{-1}$ day $^{-1}$ ecadotril reduced heart weight/body weight ratio by $10 \%$. Moreover, administration of ecadotril to perindopril-treated rats increased cardiac BK-(1-9) levels by more than 2-fold (Figure 6). BK-(1-9) has cardioprotective actions and many studies demonstrate a role for kinin peptides in mediating the cardiac effects of ACE inhibitors $(39,41)$, including the prevention of cardiac hypertrophy by these compounds $(51,52)$. Thus, the increased cardiac BK-(1-9) levels we observed in rats with myocardial infarction receiving combined NEP/ACE inhibition may have contributed to the reduction of cardiac hypertrophy in these rats.

\section{Interaction between the renin- angiotensin system and the kallikrein-kinin system}

Antagonists of the type 1 Ang II $\left(\mathrm{AT}_{1}\right)$ receptor increase plasma renin levels (19), and the resultant increase in Ang II levels would be expected to stimulate type 2 Ang II $\left(\mathrm{AT}_{2}\right)$ receptors. A number of studies suggest that the $\mathrm{AT}_{2}$ receptor may interact with the kallikrein-kinin system (53). Wiemer et al. $(54,55)$ reported that the Ang II-mediated increase in cyclic GMP production by endothelial cells was blocked by icatibant, by a nitric oxide synthase inhibitor, and by an $\mathrm{AT}_{2}$ receptor antagonist. Furthermore, these authors found that the combined administration of Ang II and an $\mathrm{AT}_{1}$ receptor antagonist reduced reperfusion arrhythmias of ischaemic rat heart, effects that were blocked by icatibant or nitric oxide synthase inhibition; moreover, arrhythmias were aggravated by $\mathrm{AT}_{2}$ receptor antagonism. These findings led Wiemer et al. $(54,55)$ to suggest that the effect of $\mathrm{AT}_{1}$ receptor antagonists may in part be mediated by increased endogenous bradykinin peptide levels consequent to stimulation of $\mathrm{AT}_{2}$ receptors by the increased endogenous Ang II levels that accompany $\mathrm{AT}_{1}$ receptor antagonism.

More recently, Liu et al. (41) reported that the reduction of left ventricular volumes by $\mathrm{AT}_{1}$ receptor antagonism in rats with myocardial infarction-induced heart failure was partially prevented by either $\mathrm{AT}_{2}$ receptor or $\mathrm{B}_{2}$ receptor antagonism. Furthermore, Tsutsumi et al. (56) reported that $\mathrm{AT}_{2}$ receptor over-expression in vascular smooth muscle cells of transgenic mice prevented the pressor effects of Ang II, and the pressor effect of Ang II was restored by either $\mathrm{AT}_{2}$ or $\mathrm{B}_{2}$ receptor antagonism. Moreover, these transgenic mice had increased kinin-forming activity in their vasculature. Further evidence for a role for the $\mathrm{AT}_{2}$ receptor in regulation of kinin production was obtained in studies by Siragy et al. $(57,58)$. Siragy et al. (57) reported that renin inhibition, but not $\mathrm{AT}_{1}$ receptor antagonism, decreased immunoreactive kinin peptide levels in renal interstitial fluid collected by microdialysis probe from sodium-deficient dogs, suggesting that Ang II tonically stimulates renal kinin peptide production by a non- $\mathrm{AT}_{1}$ receptor mechanism. Moreover, both a low sodium diet and Ang II infusion increased immunoreactive kinin peptide levels in renal interstitial fluid of control mice but not in $\mathrm{AT}_{2}$ receptor gene knockout mice (58).

Our own studies do not support the hypothesis that the $\mathrm{AT}_{2}$ receptor regulates kinin peptide production. We studied the effects of losartan administration $(10 \mathrm{mg} / \mathrm{kg}, 12$ hourly, by intraperitoneal injection for 8 days) on circulating and tissue levels of angiotensin and bradykinin peptides in male Sprague Dawley rats (19). Despite increased Ang II levels in blood, heart, adrenal, lung, and aorta, losartan did not increase kinin peptide levels in blood or any tissue. By contrast, losartan reduced kidney levels of BK-(1-7) and BK-(1-9), and reduced blood levels of BK-(1-8) to $43 \%$ of control. We also measured kinin peptide levels in the TGR(mRen-2)27 rat, a transgenic Sprague 
Dawley rat with widespread tissue expression of the mouse Ren-2 gene (18). The TGR(mRen-2)27 rat has increased Ang II levels in blood and tissues. In comparison with normal Sprague Dawley rats, TGR(mRen-2)27 rats had increased BK-(1-9) levels in brown adipose tissue (1.9-fold) and lung (1.6-fold). Together, these studies suggest that Ang II may tonically stimulate kinin peptide formation by an $\mathrm{AT}_{1}$ receptor mechanism.

In addressing the discrepancies between our own studies and those suggesting interaction between $\mathrm{AT}_{2}$ receptor activation and the kallikrein-kinin system, it should be noted that, apart from the studies of Siragy et al. $(57,58)$, kinin peptide levels were not measured. Moreover, Siragy et al. measured immunoreactive kinin peptides in fluid collected from an indwelling microdialysis probe. As noted above, the identity of the immunoreactive material is uncertain, as is the effect of the chronically indwelling microdialysis probe on kinin peptide formation. Given that our studies do not support the proposed stimulation of kinin peptide formation by $\mathrm{AT}_{2}$ receptor activation, it is appropriate to consider other mechanisms of interaction between the $\mathrm{AT}_{2}$ receptor and the $\mathrm{B}_{2}$ receptor. As discussed above, there is evidence for cross-talk between the ACE enzyme and the $\mathrm{B}_{2}$ receptor and a similar cross-talk may exist between the $\mathrm{AT}_{2}$ receptor and the $\mathrm{B}_{2}$ receptor.

Another potential interaction between the renin-angiotensin system and the kallikreinkinin system may be the modulation of the renin-angiotensin system by kinin peptide levels. Kinin peptide administration increases renin secretion $(59,60)$, possibly mediated by increased nitric oxide formation (61), and icatibant is reported to decrease plasma renin levels in anaesthetized rabbits (62), suggesting that endogenous kinin peptides may tonically stimulate renin secretion. Moreover, the location of $\mathrm{B}_{2}$ receptors in the kidney is predominantly in the renal tubules, vascular endothelium, and renomedullary interstitial cells of the renal medulla (63), locations appropriate for the modification of renin secretion, possibly by modifying sodium delivery to the macula densa. We examined whether endogenous kinin peptides modulate angiotensin peptide levels by administering icatibant $(1 \mathrm{mg} / \mathrm{kg})$ to rats by intraperitoneal injection and measuring circulating and tissue levels of angiotensin peptides after $4 \mathrm{~h}$ (25). Icatibant did not influence plasma levels of renin, angiotensinogen, ACE, NEP, or circulating or tissue levels of angiotensin peptides. This study demonstrated that endogenous kinin peptide levels acting through the $\mathrm{B}_{2}$ receptor did not modulate the reninangiotensin system. Our findings are supported by the failure of icatibant administration for 7 days to modify renin mRNA levels in kidney of adult rats (64), and the normal plasma renin levels and normal renin and $\mathrm{AT}_{1}$ receptor mRNA levels in kidney of the $\mathrm{B}_{2}$ receptor gene knockout mouse (8).

\section{Summary and conclusions}

Measurement of individual kinin peptides gives important information about the functioning of the kallikrein-kinin system. Peptide levels result from the interaction of a variety of kinin-forming enzymes, kininogens, kininases, and other factors that modulate the activity of kinin-forming enzymes and kininases. Some of the complexities of regulation of kinin peptides are revealed by measurement of kinin peptides in blood and tissues, in particular in man where the separate measurement of bradykinin and kallidin peptides gives information about the plasma and tissue kallikrein-kinin systems, respectively. The main site of formation of kinin peptides is in tissue, and our studies indicate differences between tissues and probable differences between different compartments within a tissue in the regulation of local kinin peptide levels. Our findings of increased cardiac BK-(1-9) levels in rats with myocar- 
dial infarction, and increased tissue BK-(1-9) levels in diabetic rats and in SHR are consistent with a role for BK-(1-9) in the pathogenesis of these conditions. Our studies in man suggest a role for bradykinin peptides in the pathogenesis of interstitial cystitis, whereas we found evidence for suppression of the activity of the tissue kallikrein-kinin system in patients with severe cardiac failure. The differential effects of ACE and NEP inhibition on kinin peptide levels in different tissues probably reflect the varying contribution of ACE and NEP to kinin metabolism in different tissues and tissue compartments. New methodologies are required to further elucidate the regulation of kinin peptide levels in individual tissue compartments, and the role of local tissue kinin peptides in physiology and disease states.

\section{References}

1. Bhoola $K D$, Figueroa $C D \&$ Worthy $K$ (1992). Bioregulation of kinins: Kallikreins, kininogens, and kininases. Pharmacological Reviews, 44: 1-80.

2. Foucart S, Grondin L, Couture R \& Nadeau $R$ (1997). Modulation of noradrenaline release by $B_{1}$ and $B_{2}$ kinin receptors during metabolic anoxia in the rat isolated atria. Canadian J ournal of Physiology and Pharmacology, 75: 639-645.

3. Schremmer-Danninger $E$, Öffner $A$, Siebeck M \& Roscher AA (1998). B1 bradykinin receptors and carboxypeptidase $M$ are both upregulated in the aorta of pigs after LPS infusion. Biochemical and Biophysical Research Communications, 243: 246-252.

4. Regoli D, Rhaleb N-E, Drapeau G, Dion S, Tousignant $C, D^{\prime}$ Orléans-J uste $P \&$ Devillier $P$ (1989). Basic pharmacology of kinins: pharmacologic receptors and other mechanisms. Advances in Experimental Medicine and Biology, 247A: 399-407.

5. Kato H \& Enjyoji K (1992). Hydroxylated kininogens and kinins. In: Fritz $\mathrm{H}$, MüllerEsterl W, Jochum M, Roscher A\& Luppertz K (Editors), Recent Progress on Kinins. Biochemistry and Molecular Biology of the Kallikrein-Kinin System. Birkhäuser Verlag, Basel, 217-224.

6. Stormorken H, Briseid K, Hellum B, Hoem NO, J ohansen HT \& Ly B (1990). A new case of total kininogen deficiency. Thrombosis Research, 60: 457-467.

7. Colman RW, Bagdasarian A, Talamo RC, Scott CF, Seavey M, Guimaraes J A, Pierce J V \& Kaplan AP (1975). Williams trait. Human kininogen deficiency with diminished levels of plasminogen proactivator and prekallikrein associated with abnormalities of the Hageman factor-dependent pathways. J ournal of Clinical Investigation, 56: 1650-1662.
8. Madeddu $\mathrm{P}$, Varoni MV, Palomba $\mathrm{D}$, Emanueli C, Demontis MP, Glorioso N, Dessì-Fulgheri $P$, Sarzani $R \&$ Anania $V$ (1997). Cardiovascular phenotype of a mouse strain with disruption of bradykinin $B_{2}$-receptor gene. Circulation, 96: 3570-3578.

9. Yang XP, Liu YH, Scicli GM, Webb CR \& Carretero OA (1997). Role of kinins in the cardioprotective effect of preconditioning - Study of myocardial ischemia/reperfusion injury in $\mathrm{B}_{2}$ kinin receptor knockout mice and kininogen-deficient rats. Hypertension, 30: 735-740.

10. Damas J (1996). The Brown Norway rats and the kinin system. Peptides, 17: 859872.

11. Katori M \& Majima M (1996). Pivotal role of renal kallikrein-kinin system in the development of hypertension and approaches to new drugs based on this relationship. J apanese J ournal of Pharmacology, 70: 95-128.

12. Sato $F \&$ Nagasawa $S$ (1988). Mechanism of kinin release from human low-molecular-mass-kininogen by the synergistic action of human plasma kallikrein and leukocyte elastase. Biological Chemistry Hoppe-Seyler, 369: 1009-1017.

13. Kozik A, Moore RB, Potempa J , Imamura T, Rapala-Kozik M \& Travis J (1998). A novel mechanism for bradykinin production at inflammatory sites. Diverse effects of a mixture of neutrophil elastase and mast cell tryptase versus tissue and plasma kallikreins on native and oxidized kininogens. J ournal of Biological Chemistry, 273: 33224-33229.

14. Campbell DJ, Kladis A \& Duncan A-M (1993). Bradykinin peptides in kidney, blood, and other tissues of the rat. Hypertension, 21: 155-165.

15. Campbell DJ , Lawrence AC, Kladis A \&
Duncan A-M (1995). Strategies for measurement of angiotensin and bradykinin peptides and their metabolites in central nervous system and other tissues. In: Smith Al (Editor), Methods in Neurosciences. Vol. 23. Peptidases and Neuropeptide Processing. Academic Press, Orlando, 328-343.

16. Duncan A-M \& Campbell DJ (1993). Measurement of bradykinin peptides in plasma and tissues. Current Opinion in Investigational Drugs, 2: 1181-1190.

17. Campbell DJ, Kladis A \& Duncan A-M (1994). Effects of converting enzyme inhibitors on angiotensin and bradykinin peptides. Hypertension, 23: 439-449.

18. Campbell DJ , Rong P, Kladis A, Rees B \& Skinner SL (1995). Angiotensin and bradykinin peptides in the TGR(mRen-2)27 rat. Hypertension, 25: 1014-1020.

19. Campbell DJ, Kladis A \& Valentijn AJ (1995). Effects of losartan on angiotensin and bradykinin peptides, and angiotensin converting enzyme. J ournal of Cardiovascular Pharmacology, 26: 233-240.

20. Duncan A-M, Burrell LM, Kladis A \& Campbell DJ (1996). Effects of angiotensin converting enzyme inhibition on angiotensin and bradykinin peptides in rats with myocardial infarction. J ournal of Cardiovascular Pharmacology, 28: 746-754.

21. Duncan AM, Burrell LM, Kladis A \& Campbell DJ (1997). Angiotensin and bradykinin peptides in rats with myocardial infarction. J ournal of Cardiac Failure, 3: 41-52.

22. Anastasopoulos $F$, Leung $R$, Kladis $A$, J ames GM, Briscoe TA, Gorski TP \& Campbell DJ (1998). Marked difference between angiotensin-converting enzyme and neutral endopeptidase inhibition in vivo by a dual inhibitor of both enzymes. J ournal of Pharmacology and Experimen- 
tal Therapeutics, 284: 799-805.

23. Campbell DJ , Anastasopoulos F, Duncan A-M, J ames GM, Kladis A \& Briscoe TA (1998). Effects of neutral endopeptidase inhibition and combined angiotensin converting enzyme and neutral endopeptidase inhibition on angiotensin and bradykinin peptides in rats. J ournal of Pharmacology and Experimental Therapeutics, 287: 567-577.

24. Duncan AM, J ames GM, Anastasopoulos F, Kladis A, Briscoe TA \& Campbell DJ (1999). Interaction between neutral endopeptidase and angiotensin converting enzyme inhibition in rats with myocardial infarction: effects on cardiac hypertrophy and angiotensin and bradykinin peptide levels. J ournal of Pharmacology and Experimental Therapeutics, 289: 295-303.

25. Campbell DJ , Kladis A, Briscoe TA \& Zhuo J (1999). Type 2 bradykinin-receptor antagonism does not modify kinin or angiotensin peptide levels. Hypertension, 33: 1233-1236.

26. Campbell DJ, Kelly DJ, Wilkinson-Berka J L, Cooper ME \& Skinner SL (1999). Increased bradykinin and "normal" angiotensin peptide levels in diabetic SpragueDawley and transgenic (mRen-2)27 rats. Kidney International, 56: 211-221.

27. Su J B, Barbe F, Crozatier B, Campbell DJ \& Hittinger $L$ (1999). Increased bradykinin levels accompany the hemodynamic response to acute inhibition of angiotensin converting enzyme in dogs with pacinginduced heart failure. J ournal of Cardiovascular Pharmacology, 34: 700-710.

28. Rosamilia A, Clements JA, Dwyer PL, Kende M \& Campbell DJ (1999). Activation of the kallikrein-kinin system in interstitial cystitis. J ournal of Urology, 162: 129-134.

29. Campbell DJ, Duncan A-M \& Kladis A (1999). Angiotensin converting enzyme inhibition modifies angiotensin, but not kinin peptide levels in human atrial tissue. Hypertension, 34: 171-175.

30. Duncan A-M, Kladis A, J ennings GL, Dart AM, Esler M \& Campbell DJ (2000). Kinins in humans. American J oumal of Physiology, 278: R897-R904.

31. Nussberger J, Cugno M, Amstutz C, Cicardi M, Pellacani $A \&$ Agostoni $A$ (1998). Plasma bradykinin in angiooedema. Lancet, 351: 1693-1697.

32. Campbell DJ, Duncan AM, Kladis A \& Harrap SB (1995). Increased levels of bradykinin and its metabolites in tissues of young spontaneously hypertensive rats. J ournal of Hypertension, 13: 739746.
33. Schölkens BA, Linz W \& Konig W (1988). Effects of the angiotensin converting enzyme inhibitor, ramipril, in isolated ischemic rat heart are abolished by a bradykinin antagonist. J ournal of Hypertension, 6 (Suppl 4): S25-S28.

34. Linz W, Martorana PA \& Schölkens BA (1990). Local inhibition of bradykinin degradation in ischemic hearts. J ournal of Cardiovascular Pharmacology, 15 (Suppl 6): S99-S109.

35. Zatz R, Meyer TW, Rennke HG \& Brenner BM (1985). Predominance of hemodynamic rather than metabolic factors in the pathogenesis of diabetic glomerulopathy. Proceedings of the National Academy of Sciences, USA, 82: 5963-5967.

36. O'Sullivan J B \& Harrap SB (1995). Resetting blood pressure in spontaneously hypertensive rats: the role of bradykinin. Hypertension, 25: 162-165.

37. Pravenec M, Kren V, Kunes J , Scicli AG, Carretero OA, Simonet L\& Kurtz TW (1991). Cosegregation of blood pressure with a kallikrein gene family polymorphism. Hypertension, 17: 242-246.

38. Siragy HM, Jaffa AA \& Margolius HS (1997). Bradykinin $B_{2}$ receptor modulates renal prostaglandin $E_{2}$ and nitric oxide. Hypertension, 29: 757-762.

39. Linz W, Wiemer G, Gohlke $P$, Unger $T$ \& Schölkens BA (1995). Contribution of kinins to the cardiovascular actions of angiotensin-converting enzyme inhibitors. Pharmacological Reviews, 47: 25-49.

40. Gainer J V, M orrow J D, Lovelend A, King DJ \& Brown NJ (1998). Effect of bradykinin-receptor blockade on the response to angiotensin-converting-enzyme inhibitor in normotensive and hypertensive subjects. New England J ournal of Medicine, 339: 1285-1292.

41. Liu YH, Yang XP, Sharov VG, Nass O, Sabbah HN, Peterson E \& Carretero OA (1997). Effects of angiotensin-converting enzyme inhibitors and angiotensin II type 1 receptor antagonists in rats with heart failure - Role of kinins and angiotensin II type 2 receptors. J ournal of Clinical Investigation, 99: 1926-1935.

42. Graf $K$, Koehne $P$, Gräfe $M$, Zhang $M$, Auch-Schwelk W \& Fleck E (1995). Regulation and differential expression of neutral endopeptidase 24.11 in human endothelial cells. Hypertension, 26: 230-235.

43. Rosenbaum $C$, Cardozo $C \& \&$ Lesser $M$ (1995). Degradation of lysylbradykinin by endopeptidase 24.11 and endopeptidase 24.15. Peptides, 16: 523-525.

44. Ersahin Ç \& Simmons WH (1997). Inhibition of both aminopeptidase $P$ and angio- tensin-converting enzyme prevents bradykinin degradation in the rat coronary circulation. J ournal of Cardiovascular Pharmacology, 30: 96-101.

45. Greene LJ , Camargo ACM, Krieger EM, Stewart J M \& Ferreira SH (1972). Inhibition of the conversion of angiotensin I to II and potentiation of bradykinin by small peptides present in Bothrops jararaca venom. Circulation Research, 30 \& 31 (Suppl II): II-62-II-71.

46. Campbell DJ (1995). Angiotensin converting enzyme (ACE) inhibitors and kinin metabolism: Evidence that ACE inhibitors may inhibit a kininase other than ACE. Clinical and Experimental Pharmacology and Physiology, 22: 903-911.

47. Hooper NM, Hryszko J , Oppong SY \& Turner AJ (1992). Inhibition by converting enzyme inhibitors of pig kidney aminopeptidase P. Hypertension, 19: 281-285.

48. Stewart J M, Ferreira SH \& Greene LJ (1971). Bradykinin potentiating peptide PCA-Lys-Trp-Ala-Pro. An inhibitor of the pulmonary inactivation of bradykinin and conversion of angiotensin I to II. Biochemical Pharmacology, 20: 1557-1567.

49. Marcic B, Deddish PA, J ackman HL \& Erdos EG (1999). Enhancement of bradykinin and resensitization of its B2 receptor. Hypertension, 33: 835-843.

50. Benzing $T$, Fleming I, Blaukat A, MüllerEsterl W \& Busse R (1999). Angiotensinconverting enzyme inhibitor ramiprilat interferes with the sequestration of the B2 kinin receptor within the plasma membrane of native endothelial cells. Circulation, 99: 2034-2040.

51. Linz W \& Schölkens BA (1992). A specific $\mathrm{B}_{2}$-bradykinin receptor antagonist $\mathrm{HOE}$ 140 abolishes the antihypertrophic effect of ramipril. British J ournal of Pharmacology, 105: 771-772.

52. McDonald KM, MockJ, D'Aloia A, Parrish T, Hauer K, Francis G, Stillman A \& Cohn J N (1995). Bradykinin antagonism inhibits the antigrowth effect of converting enzyme inhibition in the dog myocardium after discrete transmural myocardial necrosis. Circulation, 91: 2043-2048.

53. Searles CD \& Harrison DG (1999). The interaction of nitric oxide, bradykinin, and the angiotensin II type 2 receptor: lessons learned from transgenic mice. J ournal of Clinical Investigation, 104: 10131014

54. Wiemer G, Schölkens BA, Wagner A, Heitsch H \& Linz W (1993). The possible role of angiotensin II subtype $\mathrm{AT}_{2}$ receptors in endothelial cells and isolated ischemic rat hearts. J ournal of Hyperten- 
sion, 11 (Suppl 5): S234-S235.

55. Wiemer G, Schölkens BA, Busse $R$, Wagner A, Heitsch H \& Linz W (1993). The functional role of angiotensin II-subtype $\mathrm{AT}_{2}$-receptors in endothelial cells and isolated ischemic rat hearts. Pharmaceutical and Pharmacological Letters, 3: 24-27.

56. Tsutsumi $Y$, Matsubara $H$, Masaki $H$, Kurihara H, MurasawaS, Takai S, Miyazaki M, Nozawa $Y$, Ozono R, Nakagawa $K$, Miwa T, Kawada N, Mori Y, Shibasaki Y, Tanaka Y, Fujiyama S, Koyama Y, Fujiyama A, Takahashi H \& Iwasaka T (1999). Angiotensin II type 2 receptor overexpression activates the vascular kinin system and causes vasodilation. J ournal of Clinical Investigation, 104: 925-935.

57. Siragy HM, J affa AA, Margolius HS \& Carey RM (1996). Renin-angiotensin system modulates renal bradykinin produc- tion. American J ournal of Physiology, 271: R1090-R1095.

58. Siragy HM, Inagami T, Ichiki $T \&$ Carey RM (1999). Sustained hypersensitivity to angiotensin II and its mechanism in mice lacking the subtype-2 (AT2) angiotensin receptor. Proceedings of the National Academy of Sciences, USA, 96: 6506-6510.

59. Yamamoto A, Keil LC \& Reid IA (1992). Effect of intrarenal bradykinin infusion on vasopressin release in rabbits. Hypertension, 19: 799-803.

60. Beierwaltes WH, Prada \& \& Carretero OA (1985). Kinin stimulation of renin release in isolated rat glomeruli. American J ournal of Physiology, 248: F757-F761.

61. Schricker K, Hegyi I, Hamann M, Kaissling B \& Kurtz A (1995). Tonic stimulation of renin gene expression by nitric oxide is counteracted by tonic inhibition through angiotensin II. Proceedings of the National Academy of Sciences, USA, 92: 80068010.

62. Chiu N \& Reid IA (1997). Role of kinins in basal and furosemide-stimulated renin secretion. J oumal of Hypertension, 15: 517521.

63. Dean R, Murone C, Lew RA, Zhuo J L, Casley D, Müller-Esterl W, Alcorn D \& Mendelsohn FAO (1997). Localization of bradykinin $B_{2}$ binding sites in rat kidney following chronic ACE inhibitor treatment. Kidney International, 52: 1261-1270.

64. Yosipiv IV \& El-Dahr SS (1995). Developmental regulation of ACE gene expression by endogenous kinins and angiotensin II. American J ournal of Physiology, 269: F172-F179. 


\section{THE NOVARTIS FOUNDATION BURSARY SCHEME}

promoting excellence in science worldwide
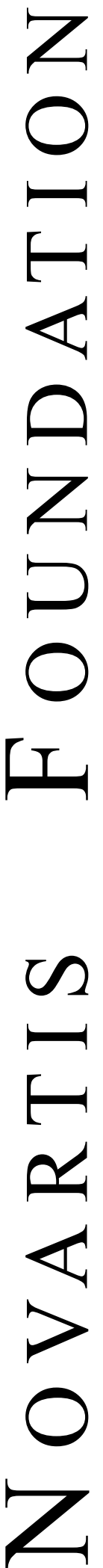

\section{INTRODUCTION}

The Novartis Foundation bursary scheme is linked to the Novartis Foundation symposia. This scheme enables one young scientist to attend a Novartis Foundation symposium (in London except where otherwise specified) and immediately following the meeting to spend a period in the laboratory of one of the participants.

\section{DURATION AND FORMAT}

The bursary is granted for a period of up to three months which includes travel, attendance at a Novartis symposium and from four to twelve weeks visiting a participant's laboratory. The actual period will be agreed between the host and bursar.

\section{BURSARS}

Bursars must be aged 23-35 and actively engaged in research in the field in question. They should not already have accepted an invitation to participate in that symposium. Successful candidates are expected to submit a short report following their return home.

\section{PROCEDURE}

Making the bursaries known: The availability of the bursaries is advertised by circular to overseas members of the Foundation's Scientific Advisory Panel, to invited symposiasts and by an advertisement in Nature, or other journal if more appropriate. Bursaries are advertised every 3-6 months, and at least six months before the date of the relevant meeting.

Applying: We do not issue application forms. Written applications should be made to the Bursary Scheme Administrator at the Novartis Foundation, including the following information:

- Full name, address, birthdate

- Title of symposium for which applying

- Qualifications and short resumé of further education
- Career history, including full list of publications

- Full details of current research

- Aims of future career

- Name \& address of two referees

Selection of the bursar: This is made by the Foundation's senior staff, usually around four months before the symposium.

Which laboratory/department? Offers to host a bursar are sought from symposiasts at the time of invitation to the symposium. The successful bursar is asked to select three names from the membership list of the symposium and every effort is made by the Novartis Foundation to accommodate the bursar's choice.

\section{VALUE OF THE BURSARY}

\section{The bursary covers the following:}

- All the bursar's travel expenses using the cheapest, most practicable and direct means of travel (i.e. economy class fares using APEX fares whenever possible).

- Bed and breakfast accommodation during the symposium week, with an allowance for meals.

Board and lodging during the candidate's visit to the host laboratory.

It is expected that the bursar will be able to stay in university accommodation or, if that is not available, in a modestly priced hotel.

\section{CONTACT}

Novartis Foundation Bursary Scheme Administrator, 41 Portland Place, London W1N 4BN, UK. E-mail: bursary@novartisfound.org.uk 